\title{
CORRESPONDENCE
}

\section{ON ALGAL LIMESTONES AT THE BASE OF THE BURDIEHOUSE LIMESTONE, NEAR BURDIEHOUSE, MIDLOTHIAN}

SIR,-Although the occurrence of algal limestones at the base of the Burdiehouse Limestone at several localities in the Central Coalfield of Scotland has been known for many years, curiously enough their presence has never been observed in the type district near Edinburgh. We therefore desire to record that this gap in our knowledge has now been filled. During a recent visit to the mine at Straiton, near Burdiehouse, we found large blocks of algal limestone on the waste-heap, and on inquiry we learned that they had lately been removed from the floor of the Burdiehouse bed during road repairs in the underground workings.

The algal limestones here are in two layers, each being slightly less than one foot in thickness, and separated by a conspicuous sun-cracked bedding plane. The lower bed which rests on a yellowish sandstone, also exhibiting numerous sun-cracks, is made up of small round algal bodies resembling oolite grains, and associated with them are large sphaeroid masses showing the characteristic structure of Spongiostromids. The upper layer is a dark grey reef-like limestone displaying a similar concentric structure, and has a smooth or warty bulbous exterior, identical in appearance with that of the equivalent bed at Rosyth and other places in the coalfield. Dr. F. W. Anderson, who has kindly examined some of the specimens submitted by us, reports on them as follows :-

" Similar algal concretions to the small oolite-like bodies are found in the Pennsylvanian of North America. They have been given the generic name of Osagia by Twenhofel.

"The large spheroidal masses resemble very closely the algal genus Ottonosia Twenhofel, though here, as in other localities in Scotland, they show some features characteristic of the genus Callenia, Walcott."

The specimens are now preserved in the collections of the Geological Survey in Edinburgh.

W. Q. KeNNEDY.

J. Pringle.

16th January, 1946.

\section{ON THE NORMAL FAULTING OF RIFT VALLEY STRUCTURES}

Sirs,-I was much interested in Dr. Dixey's letter in the May-June number of the Geological Magazine for 1945. If there are clear sections in the Northern Frontier Province of Kenya, showing a transitional zone between the Jurassics and the Marehan Sandstone, the latter must be of Cretaceous Age. Our expedition was a reconnaissance only, and these sections were missed. It is possible that there are two sets of scarpforming sandstones, one above and one below the Jurassic marines, for the Wergudud Range shows all the characteristics of a fault-scarp. 
With regard to Dr. Dixey's remarks on " residuals", some confusion of thought is bound to arise on account of the impossibility exactly of defining respectively fault-scarps, fault-line scarps, and residuals, and where the one begins and the other ends. In my own writing I would not use the term " residual", except in regard to a mass which stands above the peneplane by virtue only of its greater hardness, that is a mass left upstanding above the peneplane by circum-denudation only. I would not apply it to a mass, which has been originally uplifted above the peneplane, however greatly diminished by denudation it may have become. And surely it is more logical to confine " fault-line scarp " to a scarp formed by the differential erosion of two rock masses thrown into juxta-position by a fault. As such the term is defined in most text-books, and, as such, fault-line scarps are generally easy to distinguish.

There seems to be a tendency to regard difference of level alone as indicating different cycles of erosion, though other evidence than this is really required as well. The multiplication of erosion cycles leads to the conception of long periods of rest, interrupted by short periods of movement. Dr. Dixey distinguishes between the peneplane of the Northern Frontier Province and the "main peneplain (sic)", and states that the former " belongs to a much younger cycle, which is separated from the main peneplain by scarps up to 1,000 feet in height, that are usually erosion scarps, but sometimes possibly fault-line scarps". I suggest that his " fault-line scarps" are greatly eroded fault-scarps, and, where not so, are not scarps due to erosion only, but upwarped slopes in process of denudation. A difference of level between two plateaux is no proof in itself of two erosion cycles and of two peneplanations. If, in East Africa, it is supposed that there were several peneplanations between the movements, that have undoubtedly occurred, where has the enormous resultant mass of material been deposited ? There is no sign of it off the East Coast, where depths fall rapidly to 10,000 feet. Along the sides of the rift valleys, and especially in the region of the great trough lakes, there is often a multiplication of different levels. Are not these all part of the same peneplane lowered to different levels at different times?

Surely the general conception of one Central African peneplane, dating at least from the Jurassic, and since either raised or lowered gradually along different lines, or warped up to different levels, at varying rates in different districts, there being at no time long periods of rest, surely this conception is more consonant with the physiographic evidence.

It would be of the greatest interest if the Geological Surveys of Kenya, Uganda, Tanganyika, and Rhodesia, were jointly to produce a map, say on a scale of $1: 1,000,000$, giving form-lines of all the physiographic data so far collected, and, where necessary, leaving blanks for the addition of data from future papers. Volcanoes and their modification of the physiography should also be shown. The writer has attempted to draft such a map from the existing 1:1,000,000 sheets, and from papers so far published, but there is considerable difficulty in reconciling the various projections used, and there are often undoubted errors, possibly in printing, even in the publications of the learned societies, errors which render the ready use of the pantagraph impossible. As an example at random, Dr. Dixey's map, accompanying his "Early Cretaceous Valley Floor 
Peneplain of the Lake Nyassa Region "1 shows the lines of longitude spaced further apart than the lines of latitude!

The geological surveys of the respective territories have, however, most of the original data, and a general map with sufficient detail would bring out many points of interest. One of these, which may be generally characteristic of rift valley structures, and which, we believe, has not so far been remarked upon, is the existence in the rift region of triangular upthrown blocks, apex pointing south, and with dip-slope to the north. There is a possible connection between these and the often remarked southward pointing apices of the continents, and, if so, the rift region may hold the key to the solution of the figure of the earth. The Sinai Peninsula is the most obvious example, and this is rather like a small-scale India in structure, apex uplifted and pointing south, a gentle dip to the whole peninsula and its strata to the north, and with east and west folding parallel to the shore of the Mediterranean in the north. In Tanganyika, the block with the mountain Mbeya as the southward pointing apex, and the Rukwa and Ruaha troughs as the sides is another example. ${ }^{2}$ And again the block bounded by the submarine trough off the Mombasa coast (Ruvu-Mombasa Fault) on the one side, and on the other the Pangani Valley under the Pare-Usumbara Ranges, with the southward pointing apex south-east of Tanga, is a similar structure. ${ }^{3}$

This is an intriguing matter, which can only be brought out with good physiographic surveys and good general maps.

\section{LYMINGTON,}

H. G. BusK.

HANTS.

1 Quart. Journ. Geol. Soc., xcv, 1939, plate iv.

2 Bailey Willis, East African Plateaus and Rift Valleys. Carnegie Inst. of Washington. Plate viii.

s Op. cit., plate vi. 